Original Article

\title{
Morbidities among Eclamptic Women of Lower Socioeconomic Community in a Selected Area of Bangladesh
}

\author{
Pervin $\mathrm{R}^{1}$, Halim $\mathrm{KS}^{2}$, Ara $\mathrm{N}^{3}$, Islam $\mathrm{SM}^{4}$, Nargis $\mathrm{F}^{5}$
}

\begin{abstract}
Eclampsia is a serious obstetric emergency with new onset of grand mal seizure during pregnancy or postpartum women having signs symptoms of pre-eclampsia. The sequel of severe pre-eclampsia and eclampsia includes organ failure, loss of consciousness and finally loss of lives of both mother and fetus. This study aimed to evaluate morbidity of eclamptic women at lower socioeconomic community in a selected area of Bangladesh. This descriptive cross sectional study was conducted at Sheikh Hasina Medical College Hospital (SHMC.T) of Tangail district during the period of January to December 2019. During this period 7918 admitted patients from different sub-districts (Upazilas) of this district in obstetrics ward of SHMC.T were observed and 205 diagnosed eclamptic patients were selected as respondents for this study to detect morbidities. The prevalence rate of eclampsia among the obstetrics patients was $2.6 \%$, where $81 \%$ of them were found during antepartum/ intrapartum and rest of them during postpartum period. The mean age of the eclamptic cases was $23.78 \pm 4.94$ years and more than half of them were in age group 21-30 years. Most of the cases (84\%) were from primary level or able to sign or illiterate and rest was secondary level of education. Mean age of marriage

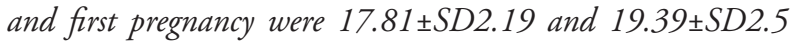
years respectively, where majority of patients were primigravida. Among the multi gravida about one fourth had 2-4 children, $16.09 \%$ had 5-6 children, where $1.46 \%$ had $\geq 7$ children and more than three-fourth of cases had 34-37 weeks of gestational
\end{abstract}

1. *Dr. Rehana Pervin, FCPS (Gynae), Assistant Professor, Department of Gynae \& Obstretics Sheikh Hasina Medical College (SHMC.T), Tangail. E-mail: dr.rehanapervin73@gmail.com

2. Dr. Kazi Shafiqul Halim, Professor, Department of Epidemiology, National Institute of Preventive and Social Medicine (NIPSOM), Mohakhali, Dahaka.

3. Dr. Noor Riffat Ara, Deputy Program Manager, (DPM, MNC \& AH), Director General of Health Services (DGHS), Mohakhali, Dhaka.

4. Dr. Syed Monirul Islam, Asstant Professor, Department of Cardiac Surgery, Sir Salimullah Medical College, Dhaka.

5. Dr. Fatema Nargis, Medical Officer, OSD, DGHS; Attached: BG Press Medical; Centre, Tejgaon, Dhaka

* For correspondence period. Among cases $95.1 \%$ had hypertension, $94.6 \%$ edema, $83.9 \%$ convulsion, $39.5 \%$ headache with blurring of vision, $22.4 \%$ severe abdominal pain, $79.0 \%$ proteinuria and $9.76 \%$ unconsciousness. Incidence of maternal morbidity during study period was $14.36 \%$, among them $9.4 \%$ pulmonary edema, $1.5 \%$ renal failure, $0.98 \%$ HELLP (Hemolysis, Elevated liver enzyme level and Low Platelet level) syndrome, 0.98\% coma and $1.5 \%$ placental abruption. Caesarean delivery was $79.2 \%$ and $11.70 \%$ was detected as postpartum haemorrhage. Among fetal morbidity $19.5 \%$ intrauterine growth restriction, $48.8 \%$ low birth weight, $39.6 \%$ birth asphyxia, and $58.5 \%$ preterm baby. During follow up only persistent hypertension was found as morbidity of eclampsia, 19.5\%, 9.8\% and 7.32\% at $2^{\text {nd }}$ week, at $\sigma^{\text {th }}$ week and at $\sigma^{\text {th }}$ months respectively. Regarding health care services $93.7 \%$ had available facility and $41.5 \%$, $47.8 \%$ and $10.7 \%$ lived in $>10$ kilometers (kms), 5-10 kms and less than $5 \mathrm{~km}$ distance respectively. Regarding $\mathrm{MCH}$ services; only $5.9 \%$ patient received antenatal care $(A N C) \geq 4$ times; more than half of them incompletely received $A N C<4$ times and $42.0 \%$ never visited for ANC. This study reveals various matters of maternal and fetal morbidities commencing from eclamptic condition in lower socioeconomic community. Here important factors for morbidities in eclamptic women like lack of ANCI PNC, availabilities of MCHC services and others. Pulmonary edema, renal failure, HELLP syndrome, coma and placental abruption are important maternal morbidities. Prematurity, low birth weight, intrauterine growth restriction and birth asphyxia are foremost fetal morbidities. Availabilities of MCH services, complete visit for ANC/ PNC and early diagnosis and management of eclamptic women positively reduce morbidity and will prevent eclampsia.

Keywards: Eclampsia, morbidities, lower socioeconomic community

\section{INTRODUCTION}

Eclampsia is a serious disease, especially in developing countries it is a major health issue and the second leading cause of maternal mortality in Bangladesh, according to report of BMMS $2010^{1}$; it contributes $20 \%$ of maternal mortality in Bangladesh.

In preeclampsia hypertension and proteinuria are present and when convulsions occur in addition to these sign the condition is referred to as eclampsia ${ }^{2}$. The clinical mani- 
festations of maternal preeclampsia are hypertension and proteinuria with or without co-existing systemic abnormalities involving the kidney, liver or blood. There is also a fetal manifestation of preeclampsia involving fetal growth restriction, reduced amniotic fluid and abnormal fetal oxygenation. HELLP syndrome is severe form of preeclampsia which involve hemolytic anemia, elevated liver enzyme and low platelet count ${ }^{2}$. Most case of eclampsia occurs in third trimester of pregnancy, with about $80 \%$ of eclamptic seizures occurring intrapartum or within the first 48 hours following delivery ${ }^{3}$. Multiple risk factors are known for development of pre eclampsia, including primiparity, maternal age over 40 years, chronic hypertension or diabetes, multiple gestation and prior history of pre eclampsia ${ }^{4}$. Prognosis of eclampsia is uncertain which depends on many factors, these are long interval between onset of fit and start of treatment, number of fit, coma, temperature over $102^{0} \mathrm{~F}$ with pulse rate $>120$ minutes, Blood pressure $>200 \mathrm{mmHg}$ systolic, oliguria $(<400 \mathrm{ml} / 24$ hours $)$ with proteinuria $>5 \mathrm{gm} / 24$ hours, non-respond to treatment and jaundice. The perinatal mortality is very high to the extent is about 30 $50 \%$, causes are mainly prematurity-spontaneous or induce, intrauterine asphyxia, effects of drugs and trauma during operative delivery. ${ }^{3}$

This descriptive study determines pattern of morbidities of eclampsia occurred in lower socioeconomic community in a selected area of Bangladesh.

\section{METHODOLOGY}

This descriptive cross sectional study was conducted at Tangail district of Bangladesh and SHMC.T was selected as a focal point for data collection. Patients were referred from different sub-districts (Sub-D) of this district and uniform representation of sample collection was maintained for each Sub-D. This study was carried out during the period of January to December 2019. All the patients of pregnant and post-partum women admitted in obstetrics ward of SHMC.T were included in this study. During study period total 7918 patients were admitted to obstetrics ward, among them 205 were eclamptic patients and selected as respondents in this study to detect morbidities. Ethical approval was taken from Bangladesh Medical Research Council (BMRC) and both verbal and written consent of patient were taken prior to data collection. Data was collected by random sampling through semi-structured questionnaire and check list. Face to face interview of patient/ patient's attendance, patient's examination, record review and bed side urine albumin test were done. Morbidities were diagnosed by examining clinical signs/ symptoms and by investigations reports (bilirubin, SGPT, SGOT, LDH, platelets count). Patients were followed from admission to discharge then at $2^{\text {nd }}$ weeks, $6^{\text {th }}$ weeks and $6^{\text {th }}$ months follow-up for long term morbidities. Data were analyzed by Statistical Package for the Social Science (SPSS).

\section{RESULTS}

The study result has been presented in tabular and graphical form as follows-.

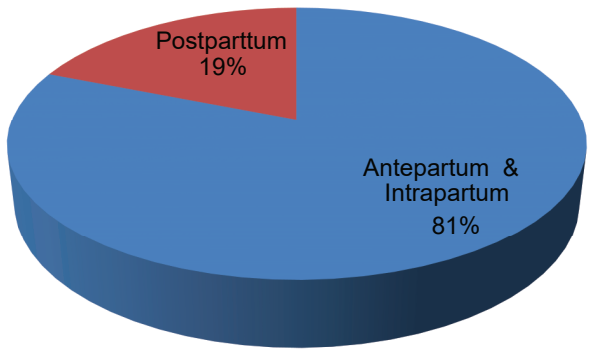

Fig.-1: Distribution of respondents according to types of eclamptic women.

Figure: 1 Shows that among 7918 admitted patients were in obstetrics ward of SHMC.T 205 patients were eclamptic. Appraised incidence of eclamptic women in this district was 26/1000 women of their natal period. Among them 166(81\%) was antepartum intrapartum and $39(19 \%)$ postpartum period.

Table I shows participant's age, ranged from 11 years to 40 years with a mean of $23.78( \pm 4.94)$ years. The highest, lowest and median age was 45,18 and 34 years respectively. About 110,(53.7\%) of the respondents were in the age group of 21-30 years which is the highest among other groups. In contrast, $80(39.0 \%)$ of the respondents in the $11-20$ age group, and slightly more than that, 15 (7.3\%) of the respondents represented the group of 31-40 years old.

Table I: Distribution of the respondents according to age of eclamptic women $(n=205)$

\begin{tabular}{|l|c|c|c|}
\hline $\begin{array}{l}\text { Age group } \\
\text { (years) }\end{array}$ & $\begin{array}{c}\text { Frequency } \\
\text { (f) }\end{array}$ & $\begin{array}{c}\text { Percentage } \\
(\%)\end{array}$ & Mean \pm SD \\
\hline $11-20$ & 80 & 39.0 & $23.78 \pm 4.94$ \\
\hline $21-30$ & 110 & 53.7 & \\
\hline $31-40$ & 15 & 7.3 & \\
\hline Total & 205 & 100.0 & \\
\hline
\end{tabular}




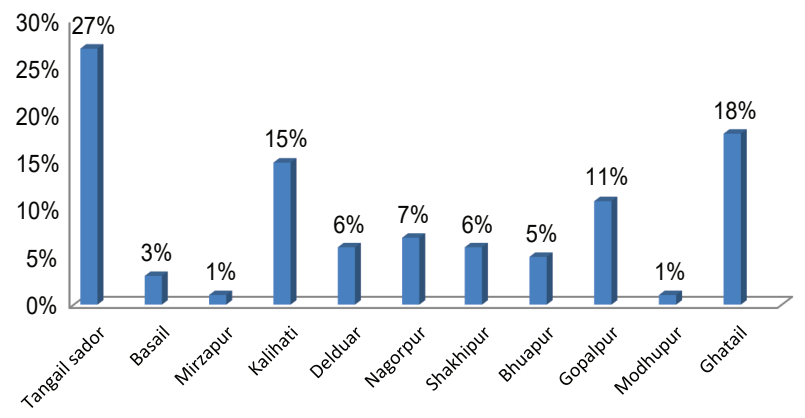

Fig.-2: Distribution of respondents according to area $(n=205)$.

Figure: 2 shows the distribution of respondents in different Sub-D, 55(27\%) were from Tangailsadar, 7(3\%) fromBasail, 01(1\%) Mirzapur, 30(15\%) Kalihat, 12(6\%) Delduar, 15(7\%) Nagarpur, 13(6\%) Shakhipur, 12(5\%) Bhuapur, 21(11\%) Gopalpur, 2(1\%) Modhupur, and $37(18 \%)$ Ghatail sub-districts.

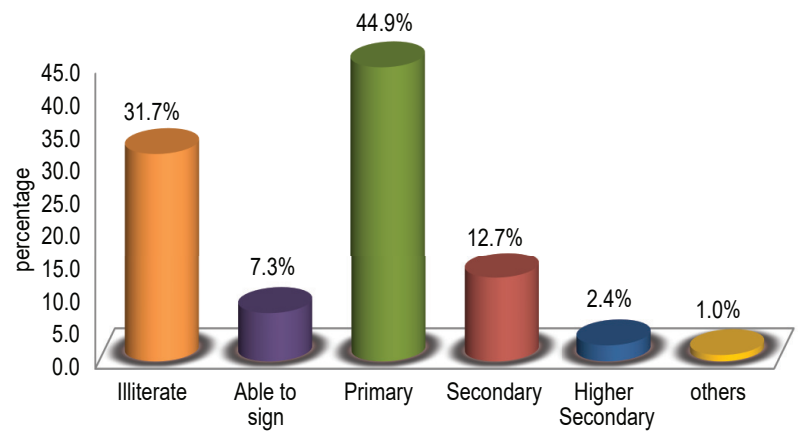

Fig.-3: Distribution of respondents according to educational status $(n=205)$.

Figure: 3 shows the distribution of educational status; 92 (44.9\%) had completed primary level, 65 (31.7\%) were illiterate, 26 (12.7\%) had completed secondary level, 15 (7.3\%) was able to sign their name, $5(2.4 \%)$ had completed higher secondary and rest of the respondents 2 $(1.0 \%)$ were in others level of education.

Table II shows the distribution of occupation and family income, 201 (98.0\%) were housewives, 2 (1\%) others occupation, where $1(0.5 \%)$ service and business. Monthly family income ranged from $00.00 \mathrm{Tk}-30000 \mathrm{TK}$ with a mean of $9129.27( \pm 4493.91) \mathrm{Tk}$, median incomes was $8000 \mathrm{Tk}$. The monthly income $00.0-10000 \mathrm{Tk}$ was 161 (78.5\%), then 10001-20000Tk was 42 (20.3\%), and the rest 2 (4\%) of them 20001Tk and above.
Table II: istribution of respondents according to occupation and family income. ( $n=205)$

\begin{tabular}{|l|c|c|}
\hline $\begin{array}{l}\text { Characteristics } \\
\text { Occupation of respondents }\end{array}$ & $\begin{array}{c}\text { Frequency } \\
\text { (f) }\end{array}$ & $\begin{array}{c}\text { Percentages } \\
\text { (\%) }\end{array}$ \\
\hline Housewife & 201 & 98.0 \\
\hline Service & 1 & 0.5 \\
\hline Business & 1 & 0.5 \\
\hline Others & 2 & 1.0 \\
\hline Total & 205 & 100.0 \\
\hline Monthly Family Income & \multicolumn{2}{|l}{} \\
\hline Upto 10000 & 161 & 78.5 \\
\hline 10001-20000 & 42 & 20.5 \\
\hline 20001 to above & 2 & 1.0 \\
\hline Total & 205 & 100.0 \\
\hline
\end{tabular}

Table III shows the distribution of first marriage and age at first pregnancy; the mean age at first marriage was 17.81 years \pm SD 2.19 and age range at first marriage 11-29 years. The mean age at first pregnancy was 19.39 years \pm SD 2.58 and age range first pregnancy was $14-30$ years.

Table- III : Distribution of respondents according to age at marriage and age at First Pregnancy. $(n=205)$

\begin{tabular}{|l|c|c|}
\hline & $\begin{array}{c}\text { Age at } \\
\text { marriage }\end{array}$ & $\begin{array}{c}\text { Age at first } \\
\text { pregnancy }\end{array}$ \\
\hline Mean & 17.81 & 19.39 \\
\hline Std. Error of Mean & .153 & .180 \\
\hline Std. Deviation & 2.191 & 2.577 \\
\hline Range & 18 & 16 \\
\hline Minimum & 11 & 14 \\
\hline Maximum & 29 & 30 \\
\hline
\end{tabular}

Table IV shows the distribution of parity, 117 (57.07\%) were primipara, $88(42.93 \%)$ multipara; according to number of children, 52 (25.37\%) had 2-4 children, 33 (16.09\%) had 5-6 children and $3(1.46 \%)$ had more than 7 children. Time duration between present and previous pregnancy, $59(28.78 \%)$ had 1-5 years' time space between past and present pregnancies, $12(5.85 \%)$ had more than 5 years, $17(8.3 \%)$ had less than 1 year. Primigravida was 117 (57.07\%). 
Table IV : Distribution of respondents according to parity: $(n=205)$

\begin{tabular}{|l|cc|}
\hline Characteristics & Frequency (f) & Percentages (\%) \\
\hline Parity & \multicolumn{2}{|c|}{} \\
\hline Primipara & 117 & 57.07 \\
\hline Multipara & 88 & 42.93 \\
\hline Total & 205 & 100.0 \\
\hline Number of Children & \multicolumn{2}{|c|}{} \\
\hline Primigravida & 117 & 57.07 \\
\hline 2-4 children & 52 & 25.37 \\
\hline 5-6 children & 33 & 16.09 \\
\hline =>7 children & 03 & 100.0 \\
\hline Total & 205 & 8.3 \\
\hline Duration of present and previous pregnancy \\
\hline$<1$ year & 17 & 28.78 \\
\hline 1-5 year & 59 & 5.85 \\
\hline$>5$ year & 12 & 57.07 \\
\hline Not applicable & 117 & 100.0 \\
\hline Total & 205 & \\
\hline
\end{tabular}

Table $\mathrm{V}$ shows the distribution of history of $(\mathrm{H} / \mathrm{O})$ eclampsia, 193 (94.14\%) had no H/O of and 12 (5.86\%) had $\mathrm{H} / \mathrm{O}$ of eclampsia.

Table V: Distribution of respondents according to H/O eclampsia $(n=205)$

\begin{tabular}{|l|cc|}
\hline Characteristics & Frequency (f) & Percentages (\%) \\
\hline History of eclampsia & & \\
\hline No & 193 & 94.14 \\
\hline Yes & 12 & 5.86 \\
\hline Total & 205 & 100.0 \\
\hline
\end{tabular}

Table VI shows the distribution of gestational period, 159 (77.6\%) were in moderate to late preterm (34-37 weeks), $19(9.3 \%)$ were in very preterm period (28-33 weeks) and $27(13.2 \%)$ were in full term ( $\geq 38$ weeks).

Table VI : Distribution of respondents gestational period during delivery $(n=205)$

\begin{tabular}{|l|c|c|}
\hline Characteristics & Frequency (f) & Percentages (\%) \\
\hline Gestational Period & & 9.3 \\
\hline Very preterm (28-33) weeks & 19 & 77.6 \\
\hline $\begin{array}{l}\text { Moderate to late Preterm } \\
\text { (34-37) weeks }\end{array}$ & 159 & 13.2 \\
\hline Full term( $\geq 38$ weeks) & 27 & 100.0 \\
\hline Total & 205 & \\
\hline
\end{tabular}

Table VII shows the distribution of denger signs, 195 (95.1) had hypertension, 194 (94.6\%) had edema, 172 (33\%) had convulsion, 14 (6.8\%) had P/V bleeding, $81(39.5 \%)$ had headache with blurring of vision, 46 (22.4\%) had severe abdominal pain, $162(79.0 \%)$ had proteinuria, 33 (16.1\%) difficulty of breathing and 20 (9.76) unconsciousness.

Table VII: Distribution of Respondents according to Danger Sign $(n=205)$

\begin{tabular}{|l|c|c|}
\hline Danger sign during pregnancy & $\begin{array}{c}\text { Present } \\
\mathbf{f ( \% )}\end{array}$ & $\begin{array}{c}\text { Absent } \\
\mathbf{f ( \% )}\end{array}$ \\
\hline Hypertension & $195(95.1)$ & $10(4.9)$ \\
\hline Edema & $194(94.6)$ & $11(5.4)$ \\
\hline Convulsion & $172(83.9)$ & $33(16.1)$ \\
\hline Headache with blurring vision & $81(39.5)$ & $124(60.5)$ \\
\hline Severe abdominal pain & $46(22.4)$ & $159(77.6)$ \\
\hline Per vaginal bleeding & $14(6.8 \%)$ & $191(93.2 \%)$ \\
\hline Proteinuria & $162(79.0)$ & $43(21.0)$ \\
\hline Difficulty in breathing & $33(16.1)$ & $172(83.9)$ \\
\hline Unconsciousness & $20(9.76)$ & $185(90.23)$ \\
\hline
\end{tabular}

${ }^{*}$ multiple responses

Table VIII shows the distribution of maternal of eclamptic women, 19 (9.4\%) had pulmonary edema, 3 (1.5\%) had Renal failure, $02(0.98 \%)$ had HELLP syndrome, $02(0.98 \%)$ had Coma, $3(1.5 \%)$ had placental abruption, $160(79.2 \%)$ Cesarean delivery and 24 (11.70\%) PPH.

\section{Table VIII: Information related to maternal morbidities due to eclampsia $(n=205)$}

\begin{tabular}{|l|c|c|}
\hline Maternal morbidities & $\begin{array}{c}\text { Frequency } \\
(\%)\end{array}$ & $\begin{array}{c}\text { Percentage } \\
(\%)\end{array}$ \\
\hline Pulmonary edema & 19 & 9.4 \\
\hline Renal Failure & 3 & 1.5 \\
\hline HELLP Syndrome & 2 & 0.98 \\
\hline Coma & 2 & 0.98 \\
\hline Placental abruption & 3 & 1.5 \\
\hline Cesarean delivery & 160 & 79.2 \\
\hline Postpartum hemorrhage (PPH) & 24 & 11.70 \\
\hline
\end{tabular}

${ }^{*}$ multiple responses 
Table IX shows the distribution of fetal morbidity, 40 (19.5\%) had intrauterine growth restriction, 100 (48.8\%) had LBW baby, $80(39.6 \%)$ had problem with birth asphyxia and 120 (58.5\%) had preterm baby.

Table IX: Information related to fetal morbidities due to eclampsia $(n=205)$

\begin{tabular}{|l|c|c|}
\hline Fetal Morbidities & $\begin{array}{c}\text { Frequency } \\
\text { (f) }\end{array}$ & $\begin{array}{c}\text { Percentage } \\
\text { (\%) }\end{array}$ \\
\hline Intrauterine growth restriction & 40 & 19.5 \\
\hline Low birth weight (LBW) & 100 & 48.8 \\
\hline Birth asphyaxia & 80 & 39.02 \\
\hline Preterm baby & 120 & 58.5 \\
\hline
\end{tabular}

*multiple respones

Table $\mathrm{X}$ shows the morbidities during follow up, 40 (19.51\%), $20((9.75 \%)$ and $15(7.32 \%)$ had persistent hypertension at $2^{\text {nd }}$ week, $6^{\text {th }}$ week and at $6^{\text {th }}$ month of follow up respectively. Others morbidities, anemia, secondary PPH, wound infection, $6(2.92 \%)$ had at $2^{\text {nd }}$ weeks, and $8(4.9 \%)$ had at $6^{\text {th }}$ weeks.

\section{Table X: Distribution of respondents according to morbidities during follow up $(n=205)$}

\begin{tabular}{|l|c|c|c|}
\hline Morbidities & 2nd weeks & 6th weeks & 6th months \\
\hline Persistent hypertension & $40(19.51 \%)$ & $20(9.76 \%)$ & $15(7.32 \%)$ \\
\hline $\begin{array}{l}\text { Others Morbidities } \\
\text { (anemia, PPH wound } \\
\text { infection) }\end{array}$ & $6(2.92 \%)$ & $8(3.90 \%)$ & 00 \\
\hline Nomorbidities found & 159(77.57\%) & 177(86.34\%) & 190(92.68\%) \\
\hline
\end{tabular}

Table XI shows the information related to health care service from respondents, 192 (93.7\%) had availability of health care facility, 13 (6.3\%) had no availability. Distance of health care facility from the residence of respondents 98 (47.8\%) came from 5-10 Kilometers (kms) distance, 85 (41.5\%) from more than $10 \mathrm{kms}$ and $22(10.7 \%)$ from less than $5 \mathrm{kms}$ distance to health care facility. Regarding ANC visits, 107 (52.2\%) partially (less than 4 times) visited for ANC during gestational period, 86 (42.0\%) never visited for any type of ANC, $12(5.9 \%)$ completed the full ANC visit ( $\geq 4$ times).
Table II: Information related to health care service $(n=205)$

\begin{tabular}{|l|c|c|}
\hline Characteristics & $\begin{array}{c}\text { Frequency } \\
\text { (f) }\end{array}$ & $\begin{array}{c}\text { Percentages } \\
\text { (\%) }\end{array}$ \\
\hline Availability of health care facility & 192 & 93.7 \\
\hline Yes & 13 & 6.3 \\
\hline No & 205 & 100.0 \\
\hline Total & 22 & 10.7 \\
\hline Distance of health care facility & \\
\hline$<5 \mathrm{~km}$ & 98 & 47.8 \\
\hline $5-10$ km & 85 & 41.5 \\
\hline$\geq 10$ km & 205 & 100.0 \\
\hline Total & 12 & 5.9 \\
\hline H/O ante-natal checkup & 107 & 52.2 \\
\hline Complete( $\geq 4$ times) & 86 & 42.0 \\
\hline Partial (<4 times) & 205 & 100.0 \\
\hline Never & \multicolumn{2}{|l}{} \\
\hline Total &
\end{tabular}

\section{LIMITATIONS OF THE STUDY}

The study population was included from one selected district of Bangladesh and data were collected from one health facility. Some patients of the selected district attended to other health facilities and some patients from border areas receive MCHC services form adjoining districts. Findings of this study may infrequently match with the actual data of the whole district and even whole country. Most of patient didn't attend any postnatal follow up; hence in some cases we collected information electronically. The study was conducted for short period with moderate sample size.

\section{DISCUSSION}

Eclampsia is still one of the important and common obstetrics Emergency in developing country like Bangladesh which has significant role of maternal and Fetal morbidities and mortalities. In this study incidence of eclampsia was $2.6 \%$ which is comparable to other developing countries with the incidence of 1 in 100 to 1 in 1700 pregnencies. ${ }^{5.6 .7}$. Simillar study done by Raji et al ${ }^{8}$ found incidence of eclampsia $0.83 \%$. In our study $81 \%$ respondents were antepartum and intrapartum, 19\% were postpartum eclampsia; similar to study Tamina et $\mathrm{al}^{9}$, reported that antepartum and intrapartum eclampsia $92 \%$, postpartum $10 \%$. This study observed that majority $(53.7 \%)$ respondents belonged to age $21-30$ years. The mean age of respondents was 23.78( \pm 4.94$)$ years. NADEEM SHAZAD et al ${ }^{10}$ observed mean age $25.17 \pm 4.9$ 
years and maximum age group 26-30 years. Ahmed Mahran et $\mathrm{al}^{11}$ showed that maternal age was major risk factor with $42.2 \%$ patients aged $<20$ years. In this study all respondents came from rural area of Tangail district and 27\% from Tangail sadar, 3\% Basail, 1\% Mirzapur, 15\% Kalihati, 6\% Delduar, 7\% Nagarpur, 6\% shakhipur, 5\% Bhuapur, 11\% Gopalpur, 1\% Modhupur and 18\% Ghatail. Nearly half of respondents (44.9\%) had completed primary level of education and $31.7 \%$ were illiterate $12.7 \%$ had completed secondary level and $7.3 \%$ able to sign. Most of respondents were housewives and belong to lower economic condition (had monthly income up to $0-10,000$ taka). Ahmed mahar et $\mathrm{al}^{11}$ showed that low socioeconomic standard obviously affected the incidence of the eclampsia. Two-third patient had no education at all and $24.8 \%$ received primary education. Meleseet $\mathrm{al}^{12}$ showed that higher the women's educational status, lower the perinatal unfavorable outcomes of severe eclampsia. The mean age at marriage was 17.81 years $\pm S D$ 2.19 and the mean age at first pregnancy was $19.39 \pm S D 2.57$. Maximum age during first pregnancy was 30 years where minimum age was 14 years. Ahmed Meharan et al. ${ }^{11}$ showed short duration of marriage was found increase risk of eclampsia. In this study $57.07 \%$ were primipara, $42.93 \%$ multipara. Among multiparous $25.3 \%$ had $2-4$ children, $16.09 \%$ had $5-6$ children and $1.46 \%$ had $\geq 7$ children. Space between present and previous pregnancy $28.78 \%$ ) had $1-5$ years, $5.85 \%$ had $\geq 5$ years and $17(8.3 \%)$ had $<01$ year gap. Pipkin FB et al ${ }^{13}$, Duckit k et $\mathrm{al}^{14}$ observed nulliparity is a well-known risk factor for eclampsia. Raji et al ${ }^{8}$ found $69.2 \%$ had primigravida, $27.4 \%$ had parity $2-4$ while $3.4 \%$ had parity between $\mathrm{p}_{5}$ and $\mathrm{p}_{6}$. NADEEM SHAHZAD et $\mathrm{al}^{10}$ found $63 \%$ was primigravida and $28 \%$ had parity $2-4$, whereas $6 \%$ was $\mathrm{p}_{5}$ $-\mathrm{p}_{6}$ and $3 \%$ had $\geq 7$. In this study $5.86 \%$ had previous $\mathrm{H} / \mathrm{O}$ pre eclampsia. Ahmed Mahranet al ${ }^{11}$ identified previous $\mathrm{H} / \mathrm{O}$ pre eclampsia in $59.6 \%$ cases. This study observed more than three-fourth had 34-37 weeks of gestation, $13.2 \%$ had $\geq 38$ weeks and 9.3\%) had 28-33 weeks of gestation. Study by NADEEM SHAHZAD et $\mathrm{al}^{10}$ showed, $39 \%$ of patient presented at gestational age of 31-36 weeks while $39 \%$ had gestational age of 37 weeks or above. It is observed that risk of eclampsia in third trimester is more. In this study $95.1 \%$ hypertention, $94.6 \%$ edema, $83.9 \%$ convulsion, 6.8 per vaginal bleeding, $39.5 \%$ headache with blurring of vision, $22.4 \%$ abdominal pain, $79.0 \%$ proteinuria, difficulty in breathing in $16.1 \%$ and $9.76 \%$ had unconsciousness; similar to study Mattar F et $\mathrm{al}^{15}$. Raji et $\mathrm{al}^{8}$ and Ahmed mahran et $\mathrm{al}^{11}$. Among the maternal morbidity (14.63\%) this study finds of pulmonary edema 9.4\%, Renal failure 1.5\%, HELLP syndrome $0.98 \%$, coma $0.98 \%$ and abruption placentae 1.5\%, chMadhuri et al. ${ }^{16}$ and Mosammot Rashida Begum et $\mathrm{al}^{17}$ found incidence of eclampsia with different complication was $21 \%$ which included renal failure $0.7 \%$, hepatic failure $0.5 \%$, heart failure $0.5 \%$, coma $2.9 \%$, pulmonary edema $10.3 \%$ and DIC $1.0 \%$ which was similar to this study. CS and PPH are not complication of eclampsia but risk for this complication is high. In this study $79.2 \%$ had CS and $11.70 \%$ developed PPH. Tulfinel et $\mathrm{al}^{18}$ reported $72 \%$ CS which is similar to this study. chMadhuri et $\mathrm{al}^{16}$ reported $6.53 \%$ PPH. In this study fetal morbidities was high and among them, 58.5\% had preterm baby, $48.8 \%$ LBW, $19.5 \%$ intrauterine growth restriction and $39.02 \%$ had problem with birth asphyxia. chMadhuri et al ${ }^{16}$ reported $30.49 \%$ prematurity, $41.47 \%$ LBW, 10\% IUGR , 14.17\% intrauterine death. Eclampsia is reported with high perinatal mortality and morbidity. It is established that early delivery reduce maternal morbidity but induced fetal prematurity. During follow up period as sequel of eclampsia only persistent hypertension was found but other morbidities like wound infection, anemia secondary PPH found in some cases; $19.5 \%$ at $2^{\text {nd }}$ weeks, $9.75 \%$ at $6^{\text {th }}$ weeks and $7.32 \%$ had persistent hypertension at $6^{\text {th }}$ months. Others morbidities were observed in $2.92 \%$ at $2^{\text {nd }}$ weeks, and $4.9 \%$ at $6^{\text {th }}$ weeks. Others morbidities are not complication of eclampsia but these worsen patient condition. We observed information related to health service, $93.7 \%$ had availability of health care facilities and $6.3 \%$ had no availability, where $41.5 \%$ had $\geq 10 \mathrm{Km}$ distance, $47.8 \%$ had $5-10 \mathrm{Km}$ and $10.7 \%$ ) had $<5 \mathrm{Km}$. Study finds that $5.9 \%$ completed $\geq 4$ ANC, 52.2\%) taken partial $(<4)$ ANC and $42 \%$ never received ANC. Ahmed Mahran et $\mathrm{al}^{11}$ showed, $30 \%$ did not attend ANC throughout pregnancy, $64.4 \%$ had $<4$ ANC. Antenatal care is important point to identify preeclamptic state.

\section{CONCLUSION}

This study reveals that eclampsia is still important cause of maternal and fetal morbidity in lower socioeconomic community. Nulliparity, primigravida, less interval in between pregnancy, pregnancy at early age, lack of education, lack of ANC and lack of health care service availabilities are important factors for morbidities in Eclamptic women. Pulmonary edema, renal failure, HELLP syndrome, coma and placental abruption are important maternal morbidities slowing to achieve MDG goal. Prematurity, low birth weight, intrauterine growth restriction and birth asphyxia are important fetal morbidities adding bulge in child health care. Proper 
antenatal care, available health care facility, early diagnosis of pre eclamptic condition, proper treatment of pre eclampsia and appropriate referreal can prevent eclmpsia and its morbidity.

\section{RECMMONDATION}

The huge prevalence rate of eclampsia during antepartum/ intrapartum period might be the major concern of health care providers. Assurance of $\mathrm{MCH}$ services for every pregnant women throughout their natal period by continuous upgrading their database and by settling ANC \& PNC (postnatal care) at Community Clinic. Prompt referral of eclamptic women to higher level health care facilities would reduce the morbidities and mortality during natal period. Thus complete visit to $\mathrm{MCH}$ services during natal period, early diagnosis and management of pre-eclamptic condition positively will reduce morbidity and will prevent eclampsia.

\section{REFERENCES:}

1. NIPORT (2012) Bangladesh maternal mortality and health care survey 2010.

2. Kejersti M . Aagaardtilery, md, phd and Micheal A. Belfort, md, phd, eclampsia :Morbidity Mortality , and management, Clinical obstetrics And Gynaecology, volume 48,Number 1,12-13.

3. DC Dutta Hiralal Konar, The Text book of obstetrics, 7th edition. Hypertensive Disorder in Pregnancy: 219-240.

4. Sijaus A, Mckeen DM, George RB. Hypertensive disorders of pregnancy. Can J Anaesth.2016; 63: 1075-97(pubmed) [Google scholar

5. World Health Organisation International Collaborative Study of Hypertensive Disorders of pregnancy. Geographic variation in the incidience of hypertension in Pregnency. Am J Obstet Gynaecol 1958: 158:80-3.

6. Crowther CA Eclampsia at Harare Maternity Hospital- An epidemiological study. S AfrMed. J. 1985; 68:927-9.

7. Bergstom S, Povey G, Songane F, chingC. Seasonal incidence of eclampsia and its relationship to meterological data in Mozambique; J Perinat Med. 1992;20:153-8.

8. Raji C., poovathi M., Nithya D. Prospective study of fetomaternal outcome in eclampsia in a tertiary care hospital .Int. J Reprod Contracept Obstet Gynaecol. 2016 Dec ;5(12):4329-4334.www.ijrcog org.

9. Tahinma HZ, Shahid AR, Hosna AU, Alam A. Study on outcome of eclampsia patients in District Hospital in Bangladesh. J Dhaka Med coll. 2014; 23(2): 223-226.

10. Nadeem Shazad, Uzma Yaqoo, Asif Hanif. Feto-Maternal Outcome in Patients with Eclampsia at A Tertiary Care Hospital. PJMHS Vol.7 No.1 Jan-Mar 2013:76-79.

11. Ahmad Mahran, Hashem Fares, Reham Elkhateeb, Mahmoud Ibrahim, Haitham Bahaa, Ahmad Sanad, et al. Risk factors and outcome of patients with eclamsia at a tertiary hospital in Egypt BMC pregnancy Childbirth. 2017;17:435. DOI 10.1186/s 12884-017-1619-7.

12. Misganaw Fikirie Melese, Marta Berta Bari and Getie lake Aynale. Perinatal outcomes of severe pre-eclampsia/ eclampsia and associated factors among mothers admitted in Amhara Region referral hospitals, North West Ethiopia,2018.BMC Res Notes (2019)12:147 https/doi.org/10.1186/s 13104-019 $-4161-\mathrm{z}$.

13. Pipkin FB. Risk factors for pre-eclampsia. NEngl J Med. 2001,344.

14. Duchit K, Hamington D. Risk factor for pre eclampsia at antenatal booking system review of controlled studies.Bmj.2005;339(749)565.pubMed PMID:15743856.pubmed central PMCID.554027.

15. Mattar F, Sibai BM. Eclampsia .V111.Risk factors for maternal morbidity. Am. J Obstet Gynaecol.2000 Feb.182 (2):307-12.

16. Ch. Madhuri , Y. Varalakshmi. Retrospective study on fetomaternal outcome in gestational hypertension, pre eclampsia and eclampsia in a tertiary care centre. Indian Journal of Basic and Applied Medical Research, September 2019;vol.8 Issue-4,p. 246-255.

17. Mosammat Rashida Begum, MBBS,FCPS, MS (MED-EDU), Anowara Begum MBBS,FCPS, Ehsan Quadir, MBBS,DCH, Sayeba Akther, MBBS, FCPS and Latifa Shamsuddin, MBBS, FCPS, Eclampsia: Still a problem in Bangladesh, National Institute of Health Journal,6(4);2004 PMC1480554.

18. Tufnell DJ. Jankowiez D, Lindow SW, Lyons G, Mason GC, Russell IF, et al. outcome of severe pre eclampsia/eclampsia. Yorkshire 1999/2003. Br J Obstet Gynecol.2005;112:875-80. 